\title{
Songs with a Message: Common Themes in Swedish 1970s Rock/Folk Songs
}

\author{
ALF ARVIDSSON
}

An alternative music scene grew in Sweden in the early 1970s. This music scene suddenly and unexpectedly created a huge impact on mass media and became a leading force that challenged conventional ideas concerning the shape and form of popular music. ${ }^{1}$ Eventually, it became known as "the progressive music movement." One effect of this movement was that lyrics about "political" topics, which were previously only heard at demonstrations and meetings of organisations, became common, even presupposed, in rock music. ${ }^{2}$ Many LP albums were produced by a few independent record companies; on the whole, they show a rich array of topics that could be understood as having a political relevance to a young audience. The movement had a broad musical profile, including a revitalisation of Swedish folk fiddling, and many groups playing instrumental music at the crossroads of rock and jazz traditions. However, this study deals only with music containing song lyrics. Of course, within a wide frame of interpretation all song lyrics can be ascribed a concrete political meaning-for example, by dealing with "harmless" themes, lyrics can serve to hide power relations and injustice, and thus have a conservative function. I am mainly interested in expressions that involve a distinct intention to pose political questions. My interest lies not with the lyricist's or singer's own stance or experience (although there was a strong emphasis on authenticity), but in the lyrics as possible to sing on a stage with an audience where themes and lyrics could have a political meaning. I have analysed the lyrics of the songs in some 120 albums. The language used in the majority of the albums was Swedish because singing in your own language achieved political status in the 1970s. Previously, Swedish rock was totally dominated by English, but with the idea that singing in English would exclude those without the necessary schooling, Swedish became the preferred language.

\section{The Swedish Context}

The Swedish scene has been internationally presented and analysed earlier (cf. Fornäs 1992, Eyerman \& Jamison 1998). Fornäs has focused upon the "progressive music movement" of the early and mid-1970s—a network of small record companies/distributors, journalists, musicians, and non-profit local clubs that provided venues for alternative music, that drew heavily on low/no-budget principles

\footnotetext{
${ }^{1}$ This is a revised version of the seventh chapter of my book Musik och politik hör ihop: Diskussioner, ställningstaganden och musikskapande 1965-1980 (Hedemora: Gidlunds förlag, 2008), being the final report of the project "Musik och politik på 1970-talet: Politiseringen av ett fält" (Music and politics in the seventies: The politicizing of a field), which was supported by the Bank of Sweden Tercentenary Fund.

${ }^{2}$ Under the period from circa 1962 to 1973, “pop” was used as a denominator for the African-American-British rock tradition, in distinction to "schlager" or Svensktopp, which was named after the Sveriges Radio Swedish language-only weekly song poll hit parade show supposedly reflecting the taste of the $20+$, a parallel to the Tio i Topp (Top 10)_English-only and for the under 20. "Rock," as in Britain, referred to the fifties rock'n'roll. Some years into the seventies, however, the American use of "rock" was adapted by journalists and musicians. (In Denmark in the sixties, the word "beat" was used instead, "pop" having more of "schlager"- connotations.)
} 
and used voluntary workers to build an alternative music scene, without the political and commercial censorship of the established society in the late 1960s. The movement had a great deal of influence on public music policy, including the broadcasting policies of the National Broadcasting System/Monopoly, Sveriges Radio (SR). This lead to a stop in the broadcasting of SR hit parades, the end of participation in the Eurovision Song Contest, the abandonment of the 'Grammy' awards by the Swedish IFPI (International Federation of Phonogram Industries), and other symbolical victories that focused on weakening the commercial music industry's dominating presence in the public sphere. The movement also (somewhat ironically but also consequentially) produced some of the decade's greatest Swedish hit albums, which included songs of explicit leftist political content.

Eyerman's and Jamison's studies situated Sweden within an international context, and primarily discussed the mobilisation of musical traditions within political movements. However, they could not restrain themselves from discussing the progressive music movement (which partly encroached on all music-making within political movements, in the way American Sing out! and Broadside magazines encroached on all political questions). An interesting point they referred to was the tensions between the music movements' early community-against-commercialism-sentiments and the later professionalism/reaching out/alliances with established showbiz-stars-tactics.

There are, however, a number of specific Swedish circumstances that should be considered. Firstly, Sweden had a high standard of living, which was in parity with the US, but at the same time more evenly distributed. Music listening and making-concerts, dancing, record buying, radio listening-became a significant common public interest. Further, Sweden had a durable and stable social democratic government (hailing back to 1932), whose intention was to reform society and to be open to modernisation. This vision of Sweden as modern and future-oriented was shared by all political parties. This included the discussions in the 1960s and early 1970s on how to organise an official governmental cultural policy in which the society (State and municipalities) would take on the public responsibilities for the Arts (or as put in Swedish, the Cultural Life). This included supporting the even distribution of art to all groups and places in society, and promoting development and quality where the commercial industry failed to do so. The interest in reforms also included new currents in pedagogy, including music pedagogy. As already indicated, Sveriges Radio had an important position in Swedish music. The SR was formally an independent foundation owned by mass media corporations and funded by obligatory receiver fees, but had an official-like position as the only legal broadcasting company. Consequently, the SR's musical programming policies had a tremendous impact on public tastes. In 1966, one of its FM channels was designated purely to art music; however, in 1962 in response to a temporary commercial offshore station, the programming of popular music was heavily increased, and included many afternoon and evening shows that were primarily aimed at entertaining the youth. In 1969, these shows became increasingly designed to reflect the general interests of the youth, which included political issues and political songs that had only been submitted to late talk shows. Finally, in 1968-69 the dominating record companies, publishers, and concert halls lost interest in rock music and (rebel) youth culture. They turned instead to the promotion of mainstream conformity 'non-rock'popular music, which left a void filled by alternative, independent, experimental, and political music. This new visibility of alternative music was reflected for instance in the SR youth radio shows, where the hosts were quite opposed to the anxiety of the elder producers, and deliberately tested the limits of what could be broadcast. 
Another aspect to reflect upon is the relation to the American folk song movement. The songs of the Kingston trio, Peter, Paul and Mary, Pete Seeger, Bob Dylan and Joan Baez were introduced as pop hit recordings and as "movement songs," and adopted both these functions in Sweden. However, the pop hit function came first in Sweden; there were hardly any political meetings, demonstrations or organisations that used songs before 1965. Whereas the Kingston trio and Peter, Paul \& Mary were groups that introduced a new format in American entertainment, (a long tradition of folk singers were recognised as a category of professional artists in Sweden ) the trubadur was a distinct role, with an established scene that largely consisted of restaurant entertainment gigs as well as radio shows. Therefore, in 1964-65 there was a "folk song boom" inspired by American models; but the new singers who caught the public eye were to a large extent part of an established entertainment business that was not particularly interested in social comment, but had a preference for humorous, romantic, and drinking songs that were suitable for restaurants, pubs, and the Swedish folk park entertainment venues all across the country. The new left-wing organisations that developed kept a rather strict control on the music that was performed at their meetings, which led to a huge corpus of songs being produced, but only a few of them reaching outside of the immediate context. Instead, the new rock scene that grew during 1969-70 became an outlet for writing songs with social and political comment that were aimed at a wider audience of young, politically-interested people. ${ }^{3}$ It also included a second generation of folk singers who worked in the Dylan tradition. Another interesting trait is how the progressive movement, with its DIY ethos, anti-commercialism, and eventual strong focus on the young and unemployed, had much in common with the British punk rock wave. However, when British punk was introduced in Sweden in 1977, a generation gap opened and Swedish punk was prominent in opposing the movement.

Accordingly, there were several currents that combined to create a special focus on music, the politics of music, and the political content of music, and these currents induced a rather widespread consciousness of these intersectional relations. Prime-time TV shows in the early 1970s carried out debates on the overt and covert political contents of leftist contra "unpolitical" singers, on censorship, on commercialism's distorting effects and practices on authentic music and authentic musical needs, and so on. Among leftist musicians, journalists, activists and supporters, the focus was not so much on the political aspects of music, but rather on how the political content of music was to be decoded, and on what musical styles and forms were politically correct. One position that was strongly promoted by some influential journalists was to concentrate on relatively simple rock music with clear lyrics in order to reach out to working class youth. Eventually, these discussions, together with a general generation change, and the sectarian practices of rebutting everything outside their own organisation's control, led to a stalemate position where the incentives for creativity had ceased to work.

\section{Some Notes on Methodology}

My analysis of the texts of Swedish folk/rock songs of the 70s consists mainly of ascribing recurrent themes to the different songs. I listened to the albums, read the lyrics whenever possible (often printed on the sleeves or an insert in order to get the message through), and read the comments

\footnotetext{
${ }^{3}$ There was also a development in international rock music that was also influential. For example, the first three albums of Mothers of Invention, Jefferson Airplane's Volunteers, Steppenwolf's Monster, all influential in Sweden at the time, not only protested against the war but also expressed a distrust of Western society in general and promoted opposition, thus pointing out one direction for the development of rock.
} 
on the album sleeves that often made the message more explicit. For each song I tried to choose some key words that were either directly from the lyrics or the title, or of my own characterisation. As this is music from my youth (I was born in 1954), I have an insider's view in relation to the age group, as well as nationality and gender. I chose between one to ten key words for each song. Sometimes I also took notes on the voice (involved, not involved; I/we; addressing to "you" and so on), mood, genre, metaphors, irony/parody, or other inter-textual relations and chronotopes. When this coding phase was completed, ${ }^{4}$ I made an alphabetical list of all the keywords and checked every occurrence. I sometimes reduced the number of key words because I had used words that were nearly synonyms and did not consider there to be a significant difference between them. Then I grouped the most frequent themes into semantic fields, which resulted in some fifteen groups. Some albums were made with a single central theme (prison life, war, women's liberation), and the reason for this is that these were common themes that were present on other albums. The groups of themes include the following: Society, power relations, class society, capitalism; work; nature and the countryside; urbanization, cities; the future, freedom, power, oppression, resistance; revolution, demonstrations; militarism, war, the war in Vietnam, the USA; escapism, drugs, social misery; ego, life, emotions; love; gender, women's situation; youth, parents, children; alienation, loneliness, togetherness, communication; commercialism, mass media, music; religion. The groupings may seem haphazard, but there are strong inter-textual bonds between the themes-one theme could one be classified as independent, but also be seen as a trope of another theme.

My presentation discusses of each group of themes, for which I try to explain the theme's relevance for a young, left-inspired audience in the early 1970s, presents how it was interpreted, and exemplifies how this was communicated in song format through the use of quotations from the lyrics. I have tried to anchor the songs in their contemporary contexts of political attitudes and life-styles, rather than, for example, in international parallels, the writer's artistic development, or lines of tradition. I have made this choice because I consider the songs to form a totality that is aimed at a huge youth audience, and as addressing the problems and issues that are of immediate interest to this audience. In other words, there is a cultural analysis frame to my presentation. The culture I refer to could be named "young and progressive," but there can also be a number of sub-categories: the political activists (who were building organisations; after 1970 a variety of new communist parties were established. These parties were small and fought each other, but did wheel considerable influence. There were also many non-party organisations), the new middle class (young teachers, social workers and so on); the social experimenters (commune builders, hippies), and young workers. These groups are partly defined in contrast to each other, but there are also overlaps.

\section{Understanding Society and its Power Relations, Consumerism, Capitalism, and Class Struggle}

Generally speaking, the new music was understood as a critique of society. The ideas and comments of society, and especially on the views of youths and the student movements, were put to music in the late 1960s. Consumer society is critiqued on a number of points: the wastefulness and luxury issues, the negative sides of urbanisation, the lack of sincerity in human relations, the

\footnotetext{
${ }^{4}$ The coding tables and the full discography are available at www8.umu.se/kultmed/personal/arvidsson/musik_politik.html
} 
commercialisation of culture and emotions and pollution. It forms a critique of the unfair distribution of the earth's resources and Western countries' exploitation of third World countries. It also critiques older power structures, laws, and norms that still regulate life. During the 1970s the critique of society was often combined with a Marxist analysis of the causes of society's problems and/or with a socialist political stance, but there were also misanthropic, sceptic, utopian, romantic, and anarchist tendencies.

Bernt Staf, a solo artist in the folk-singer tradition, wrote several songs where power structures are hastily depicted.

Leading businessmen's government mandarins

Raise the tempo at work and fool us into buying lots of junk

And if you are maladjusted to cars and non-returnable bottles

You'll be sedated in one of their new institutions

With the help of laws and police

The profits of the wealthy are defended

Against more and more homeless in the towns

(Landsbygdens avfolkning, Depopulation of the countryside, 1972)

The rock group Contact sometimes used a mythical language in order to describe a sick society. Some lyrics have an almost apocalyptic mood. In Guldkalven (The Golden Calf) there are several references to the Bible:

We are dancing around a huge golden calf

Tomorrow we will crucify your neighbour

He doubted the worth of carving for gold

He stated he was the only one

One important target of the critique is the Western society's consumer society, in which luxury goods take the place of more authentic values and fills the void of alienation. This critique was often articulated through the use of irony:

Things, things, you got to get lots of things

Or you won't feel satisfied

Colour TV, stereo kits, everything's so fine

Money, money, you got to get lots of money

Or you won't feel satisfied

A nice red sports car and a swimming pool

Everything's so fine

(Vildkaktus, Prylar, Things, 1970)

I'm sitting on top of the mount of riches

Looking down on those who struggle hard to get by

High up here I'm so secure

I've struggled hard to get here

Money is everything, you got to have

Power over everything, you got to have

(Vildkaktus, Rikedomens berg, Mountain of riches, 1970) 
Tourism can be seen as a symbol of wealth and over-consumption, and can be used critically in a comparison between Sweden's high living standard and other countries. The rise of the tourist trade was criticised for pushing aside the more genuine and valuable branches, and for commercialising native folk culture. Travelling by charter to Spain and Mallorca, which had a boom in the 1960s, made visible the comparative inequality. Charters involved cheap holidays for Swedish workers (often with heavy drinking) whereas poor Spaniards worked as their servants—all of this framed by a fascist dictatorship. In Juanita by Hoola Bandoola Band, the holiday-making children of a Swedish volunteer in the Spanish civil war (republic) are juxtaposed against the voice of a war veteran: "Here you run around supporting something he fought all his life/You should know, the tourists' money is like honey for the oppressors."

A critique of the naivety of tourism in Spain is presented in Ted Ström's Sangria: "We lie sunbathing on the frontside, never see any back side." In mass media, the song was presented as a countertext to pop hit Eviva Espana.

Societal scepticism came to focus more and more on the issue of class. The post-war view of Sweden as a democracy based on equality was challenged in public debate when Marxist economists reminded people of the strong centralization of economic power. In 1965, the New Left- inspired Communist Party leader C. H. Hermansson pointed out that there were just 15 families that controlled most of the Swedish banking world and the industries. The Wallenberg family, whose members controlled the Stockholms Enskilda Bank, and thereby some of the largest industry corporations, became personifications of capitalism. Despite campaigns from the social democratic party_ “increased equality" was their 1968 elections slogan — the critique of class society hit the party hard. It had built its 30-odd year government position on a social contract between the Unions and the employers' association of industrial peace. Minister of finance Gunnar Sträng, a former Union agitator, used to stress this in public: "What's good for Swedish trade and industry is good for the Swedish people." The stress on mutual understanding as a condition for building the welfare state had thus contributed to making class antagonisms invisible.

This Samförståndsanda (spirit of mutual understanding) that was often invoked in public was mocked several times by the group Gunder Hägg. ${ }^{5}$ A number of the songs on their first album had been produced for a radio play on the 1938 Saltsjöbaden treaty where the Swedish Confederation of Trade Unions (Landsorganisationen, LO) and the Swedish Employers' Confederation (Svenska Arbetsgivareföreningen, SAF) had agreed to try to avoid strikes and lock-outs. This was one of the corner-stones of the "Swedish model": "We sing sweet, sweet love, we sing sweet sweet love, we are so happy together in LO and SAF..." (Sweet love).

We're gonna have a good time

We're gonna have a party

O my what a good time, Ay, ay, ay

Arne plays accordion

Marcus makes the drinks

Everyone can grab, Ay, ay, ay

... such mates the guys and pals and boys at SAF and LO are

Let's have a ball

\footnotetext{
${ }^{5}$ The group took its name from the world record middle distance runner Gunder Hägg, who was flattered at first but eventually found that it affected his company negatively, so they had to change their name after three albums, to Blå Tåget.
} 
I'm getting dead drunk tonight at the Grand Hotel

(Gunder Hägg, Aj aj aj)

Hägg's $A j$ aj aj refers to the friendly atmosphere and joint dinners that were reported as characteristics of the recurrent central wage negotiations (Arne = Arne Geijer, leader of LO; Marcus = Marcus Wallenberg). The Grand Hotel in Saltsjöbaden, the site of negotiations, was owned by a Wallenberg company.

The Tigerkaka (literally, "Tiger cake" - a Swedish pastry with yellow and brown stripes; marble cake) became a metaphor for the Swedish model's blandekonomi (mixed economy) with its streaks of capitalism and socialism, but Gunder Hägg drew the metaphor further:

The cake has to be divided so everyone can eat

But everybody can't get equally fat

Some have to get more, that's obvious

Glassfabriken (the Ice Cream Factory) by the same group tells a history lesson about the development of the welfare state and the principle of mutual understanding, but also includes the principles of industrial taylorism, which involved a speeding up of work rates and an increase in worker supervision. That the ideals of equality stood in sharp contrast to the actual significance of class origin and belonging was put into words in Fickteaterns I vårt samhälle (In our society):

In our society everybody's got a chance

It just comes down to having a drive and being strenuous

To really want

And to come from a well off family

According to statistics

But, a gifted young person from the countryside

Can always go the hard way

If he really wants to, and makes an effort

Doesn't live and eat as others

Or fall in love

Or have desire

In our society everyone can be what they are born to!

Mikael Wiehe wrote several songs for Hoola Bandoola Band that distinctly concretized theories and ideas of society. Vävare-Lasse (Larry the weaver) is directly adapted from the analysis of the development of the rise of capitalism in Karl Marx' Capital and includes examples of how home-weaving peasants lost their income and were forced to work in textile factories. Keops Pyramid unites the pyramid metaphor of class society with the pyramid as a concrete working ground where working class labourers work hard to build monuments for the upper class. In an interlude, the tower of Babylon is invoked as well; the song ends by stating that all societies seem to build pyramids- "but when those up in the sky, no longer understand those down there who struggle and ask for food, the pyramids will eventually become their graves." 1789 + 0 compares the French Revolution slogan of Freedom, Equality, and Fraternity with a Swedish society that still has distinct class differences. Freedom is only for the wealthy, and individual egoism is the main principle instead of fraternity. 
Another topic that was especially popular in the middle 1970's was the increasing presence of policemen and private guardsmen in society. This issue was addressed in the following questions: Who and what is to be guarded? Who decides what is allowed in public spaces? Who should obey the commands? A certain frame of interpretation was established because of the many confrontations that took place during demonstrations and other public actions, and the feelings of young people who felt unwelcome in squares and shopping malls. It was concerned with the control of ordinary people and for protecting the property of the bourgeoisie.

Sweden had its own Watergate in 1973. The involved journalists, however, received prison sentences and the government continued to rule. During the spring of 1973, the independent leftist magazine Folket $i$ Bild/Kulturfront revealed that a secret intelligence organisation, IB, existed separately from the internal security police and had diffuse connections to the ruling social democrat party. It registered people's political opinions and had infiltrators within leftist organisations. In October, after the courts had dismissed the question of the legal grounds of IB's existence, their magazine was raided and the journalists were charged with being spies. The journalists' arrest spawned many songs that focused on the hypocrisy of the rulers and the issue of freedom of speech. The murder of singer Victor Jara in Chile during the military coupe in September was also taken up in some songs, making him a martyr for the freedom of speech and a model for musicians.

The metaphor of society as a secret control machine that works behind a democratic surface grew in stature during the 1970s. It was even given names like The Invisible Oppression (Det dolda förtrycket, Solen skiner, 1976); The Dead Zone (Döda zonen, Lars Aldman 1976) or Culture of Silence (Tystnadens kultur, Elektriska linden, 1978):

When the system is cracking

Policemen and soldiers are called up

When execution patrols and citizen's guards

Command fire

When raised voices are oppressed with extraordinary laws

Then they will show

Who is strong and who is weak

Then they show their real faces,

Then we are considered animals

It seizes by the throat

Then you feel the culture of silence

\section{People at Work}

If the radicalism of the 1960s was mainly about war and oppression in international relations, and about youth rebellion, important topics in the 1970s were work and the work-environment. The background to this change involved the critique that the new left was isolated from the majority of the people, producing an increase in militancy among the workers. Moreover, many wild-cat strikes disturbed the "mutual understanding" model, making the working class more visible in society. In 1969, an experimental collective, the NJA group, presented a play at the Royal Dramatic Theatre. The play was written together with, and focused on, the workers at the state-owned iron works NJA in the northerly town of Luleå. It combined concrete questions concerning environmental issues (working in 
dust, hot vapours, amidst poisonous materials), taylorism, ${ }^{6}$ and urbanisation, with the more general issues of class society and the credibility of the social democratic party. (As this was a state-owned industry, the party was in the position of both being employers and claiming to be the workers' party.) The songs from the play became an influential hit LP record that gave the independent record company MNW a good start.

During the 1970s, taylorism was intensively discussed in terms of its function as industrial capitalism's concrete refinement of exploitation, and in terms of its role in impoverishing the meaning of industrial work. One example is journalist Harry Braverman's book Labor and monopoly capital: the degradation of work in the $20^{\text {th }}$ century. The NJA group focused their attention on the MTM system, an advanced system for measuring the time taken for each single operation and therefore regulating the industrial worker's existence in terms of split seconds.

The effects of taylorism in relation to social exclusion and the many workers who could not keep up with the high production pace is also a recurrent topic in songs by Blå Tåget, as in Den ena handen vet vad den andra gör: ${ }^{7}$

The speed is raised at the production line

Here the elite is trained

The production has no place for him who has been worn out

But in order that no-one should think there is anything wrong with the piecework rates

He is considered a case of illness and is passed over to the merciful rehabilitation unit

Narratives from the industrial world became an important theme, as in Göran Persson's ${ }^{8}$ Englunds bygge, an autobiographical account of an angry building contractor; Röda Ropet, Nynnat och sjungit (Humming and singing), about a young worker's day; Opponer's Alfa Blues, co-written with workers at Alfa Laval, which focuses on their local union; Höj Rösten's När man kör en Scania Vabis (When you drive a Scania Vabis Truck), about a lorry driver's everyday work. Göran Persson also wrote some noted songs about being unemployed. Poet Sonja Åkesson's Den ensamma mamman i traversen (The single mother working the crane) drew attention to women in industry. Löpande bandet's En kvinna bland alla andra (A woman among all others) och Nationalteatern's Hanna frän Arlöv are other examples of narratives of women in the industry.

The NJA play was performed in the same autumn (1969) as a series of wild-cat strikes shook Swedish industry. These strikes began in the harbour of Gothenburg, but continued at Christmas in the state-owned iron ore mines, later followed by strikes at SAAB, Volvo, at the shipyards and by charwomen. Several independent theatre groups produced plays on these strikes, including songs that expressed emotions and courses of events. Nynningen's Vilda strejker lönar sig (Wild strikes do pay) and Björn Afzelius Strejkmöte (Strike rally) are general celebrations of the strike as a weapon in conflict.

\footnotetext{
${ }^{6}$ Taylorism or Scientific Management, named after engineer F W Taylor (1856-1915) is a principle of organising industries, where the production is divided into small units of operations in order to streamline the process; furthermore, the individual worker has no overview, instead supervisors and engineers control the process.

${ }^{7}$ Literally: The one hand knows what the other one does-a variation of a well-known proverb: The one hand doesn't know.... The recurrent theme of the song is how the welfare system (state) was subordinated in different fields to the needs of the industry (capital). This song was covered in 1978 by punk rock group Ebba Grön, renamed Staten och kapitalet (State and capital). In 1999 their version was voted best Swedish rock song of the $20^{\text {th }}$ century.

${ }^{8}$ Not the recent Prime Minister!
} 


\section{Nature and the Countryside-Exploited and Abandoned}

Beginning toward the end of the 1960s, a wealthy and modern society that was characterized by large cities, smog-producing industries, high degrees of stress in the treadmill, and consumption artificial status symbols, was compared with the country and nature, which represented an unaffected and natural way of life with low degrees of stress. One way to represent this change of attitude was to critique industrial production. Another way to focus on the countryside was to call attention to its problems by demanding improvements. Centralization and urbanization had dominated social planning in Sweden since the early 1950s and had resulted in the closing down of shops, village schools and farms, but also in political and geographical planning. The closure of industrial plants in small towns in combination with a harsh employment policy forced people to move. Contact summed it up in Ogräset sprider sig på vallarna (Weeds spreading on the pastures):

We lived in a little village, referred to as a thinly-populated area

The state suddenly found this isn't profitable

They close down the buses, grocery store and post office

And the school is closed one day, there are too few children

The weeds spread on the pastures

Many songs dealt with leaving home because of unemployment. For example, Contact in Minnen (Memories) says:

I see a saw-mill that no longer exists

I see my home fall into decay

All my friends have moved away

To the big city to earn a living

The group Gläns över sjö och strand, which was active 1970-71, had many songs that criticized the Swedish rural policy. Louise and Peter Mosskin were the main members of the group and had moved from Stockholm to the country. In Morfar, varför finns det bara du kvar (Grandpa, why are you the only one left) a grandchild remits critique by asking innocent questions. The grandpa persona returns in Konsum (Co-op), which narrates how the villagers once built their own grocery store only for it to be closed down by the centralized co-op corporation. Är du lönsam lille vän (Are you profitable, little friend) compares living in a small village with central planning that reduces individuals and places to unprofitable units. Issues such as urbanization, industrialization of farming, pollution, and social exclusion are transformed into a process of social change of monumental and even mythical dimensions in Bernt Staf's Fädernas missgärningar (The misdeeds of the ancestors):

Here lies what once was somebody's home

Not even the sparrow-hawk returns

Throw away what has been exchanged

For something new and supposedly better ...

The misdeeds of the bosses will return

Upon the third and fourth generation 
There is also a more positive side to the countryside that reflects a common trend in the early 1970s when "moving out to the country" was promoted as an alternative to living in choking cities. This is expressed in Splash's Ut på vischan (Out in the boondocks):

Come let's move out in the boondocks

Desert! Have a try

Open your eyes covered with dust

Wash them in clear water

Mikael Ramel tells a story about visiting a musician friend who has moved "into the woods" (Langt ut $i$ naturen, Far away in nature):

He told me that cars and city life was no music to him

I suddenly felt normal—-totally out of my attitude shell

I want to live there far away in nature

I want to let myself out of the cage

I want to be happy and free, the forest gives energy

Just on living with music

The buzz of a bee is pure harmony

The bell of the cow has a wonderful tone

I want to live the music of nature

An actual bee is heard buzzing in the microphones, and the track ends with a variety of sounds from nature and the rare "woods people" who sing and rejoice until they are scared away by Leslie, the forest lion (according to the album cover).

Bernt Staf verbalized a utopian image of a decentralized society:

When soot-flakes fall over stress and riots

People pushed together will raise their voice

At the factory gates torches of freedom shine

When workers at last see their rights

In Älmhult and in Vadstena

The population owns the lands and factories

The profits stay within the little community

Where solidarity makes everyone rich

(Morgonbladet, The Morning Paper)

Ted Ström in När vi var på hemväg (When we were homeward bound) also paints a utopian image of how the desolated suddenly come back to life:

Then the rusty plough was turned up, The hay once more was in the barn,

Everything has a purpose, a new day had come, And agriculture once more was a necessity.

The industry was closed down without oil and iron, 'Imagine they planned it so wrong'. 
The critique of big cities and urbanization, and the positing of country life as a good counterexample, was also a legitimate topic in conventional commercial pop songs. But these critiques lacked political analysis. A 1971 hit song by later ABBA singer Björn Ulvaeus addressed the depopulation of the countryside as an inevitable fact:

Now I leave the village that saw my birth

Soon it will sleep forever. .

Nevermore, nevermore, nevermore

Nobody can change what is happening

However, people in the countryside actually had started to work against the process of depopulation, as they occupied school houses and went on hunger strike. Fria Proteatern made a counter-text where Aldrig mer (nevermore) was substituted with Vi blir fler (there are becoming more of us):

More of us, more of us, more of us

If we are many we can change what's happening

The bosses are against us but we can beat them

If we gather together, more of us

There was also a left wing/Marxist critique of the romantic view of the countryside as an antimodern current. Gunder Hägg sang ironically (Uppå landet, In the country):

Far away in the country

There are no evil cities, no factories,

I weave my own clothes

And devote my time to dreamings

Another topic that formed a critique of the capitalist society and its short-sighted profit planning was environmental pollution. Trubadur Anders Fugelstad made this a song topic with his 1969 album Ingenting är längre som förut, which also included the song Nagonting gemensamt (Something in common). This song refers to the fact that everybody in the world had some DDT poison in their bodies, because of its heavy use as an agricultural weed-killer during the 1950's. The placement of a new oil refinery in a narrow fiord was lamented by Contact in Ode to a fiord:

Nevermore the sea-swallow will dive

Into the bay that once was our bay

Life is shoved out for the profit to rise

For the few but never for us

This is the end, the decision is made

All shall be sacrificed by the golden calf

This is only the beginning but soon everything

Will be covered by oil and soot

As mentioned above, the questioning of private motoring as a prerequisite for modern life was one part of a critique of urbanization and big city problems. 
Take your new car

Drive out into the country

Drive on the asphalt road

Stop at a large parking lot

You can sit and watch

All the cars

What would the forest look like

Without the cars?

(Vildkaktus, Bilen, The car)

In the songs that I have analyzed, the themes of nature and the countryside were most common during 1969-1972, but then become scarcer. This probably reflects the diminishing romanticism and growing interest in the labour movement. However, a parliament decision concerning nuclear plants in 1975 and the 1980 post-Harrisburg referendum on nuclear power initiated campaigns with many songs written against the plants.

\section{Urbanization and the Environment in the City-Questioning City Politics}

The countryside and nature were often paired with a critique of urbanization and the uninhibited growth of the big cities. Large apartment suburbs that were hastily built during the 1950's and 1960's to house those who moved from the countryside; and the immigrants, who were recruited for the industrial expansion, became symbols of short-sighted planning and the forgetting of the "little man."

Great houses grow thicker than trees in a forest

Good to see but half of them would do

Place to laugh and sing is restricted by grey concrete

And you hear the neighbour all night long

Entertainment only canned (i. e., on TV)

When it stops all is dark

It's depressing to live real suburban life

Deep inside a protest takes form

Open your door, invite your neighbour to a party

There still must be a little good will

Just you pull yourself together

People surely come out to join each other today

(Contact, grannlåten, Neighbourhood Tune)

The suburbs became a symbol of boredom. Some real suburbs were depicted in songs. I Hallonbergen, written by Leif Nylén and recorded by Marie Selander, refers to one of the new suburbs in the Stockholm region and the song is characterized in the album insert as "a picture from a new apartment area in Sundbyberg. It is supposed to be inhabited by an immigrant Finnish workforce." In the area, which is still a building site, the narrator sees a bailiff walk around with seizure commissions, a building contractor who has inspected a "heavenly grey" apartment bunker, a discharged immigrant, and a worn-out shift worker dreaming of real raspberries (the suburb's name Hallonbergen literally means Raspberry Mountains). Bergsjön describes a lonesome single mother in a Gothenburg suburb, who does 
not know any of her neighbours. Tore Berger's I Hagalund remembers a small workers' housing area that has recently been torn down. Love explosion's Rivningsrök (Demolition dust) speaks of how Landala in Gothenburg was torn down to provide space for new, expensive flats for wealthier people and ends with the conclusion "it is right to make a revolution."

\section{The Future, Freedom, Power, Oppression, Resistance, Revolution- Key Concepts for a Young Generation}

The heading of this paragraph contains a number of keywords present in the young left-inspired discourse that provided material for song topics. To live in contemporary society was to become conscious of power structures and oppression and to resist and revolt, in order to gain freedom and a (better) future. The examples I present deal with social analysis and focus on the individual and/or collective as a subject.

The Future is an important concept. It is spoken of as something positive although diffuse. The future is a different and better state than the present, something that is possible if you strive for it and do not lose hope. Freedom is sometimes a utopian freedom from outside control—as in Träd Gräs \& Stenar's I ljuset av din dag:

In the light of your day, Do what you like

In the darkness of your night, Do what you like

Everybody must have their food, come let's make it together

You are a child of the universe, so are all of us

The guiding idea of several songs is the questioning of power and powerlessness and the power structures of society (as a corrective to the idealized image of democracy where all are valued equally). Blå Tåget's Makten och friheten (Power and Freedom) discusses how freedom presupposes power. Atlantic Ocean's Take a look around you invokes us to realize what is going on: "There's a lot of manipulation, you're just nothing more than a pawn." To make resistance against oppression almost became a root metaphor for the left-wing movement. The word oppression was seldom used in direct reference to Sweden, but rather to countries where there were military governments or invasions from external forces, and in songs that more generally represented resistance and liberation movements. In Revolution (also known as Seger, Victory) the movements are posed as an international force: "The peoples have said: This is enough! Revolt!" There is a similar theme in Nynningen's Vinden förebådar stormen: "The wind in the trees forebode the storm from distant mountains." Resistance at home in Sweden is also represented in many ways: in the celebration of the wild-cat strikes, but also in minor and more humorous stories of poaching and workers stealing Christmas trees from the company. The Revolution was a symbolic concept while simultaneously something concrete. It could signify a will to change the world, to change a common consciousness, or to change your own existence on an ideological level. It could also refer to a revolution by military means-usually in the shape of a guerrilla war with bases in the villages and mountains - that is, in a landscape more reminiscent of Indochina or Latin America than of Sweden. The two understandings of revolution sometimes blend with each other in a diffuse way; it is supposedly the same struggle, but under different conditions and with different means. In Inget är längesen (Nothing is long ago) by Gunder Hägg, the message is that there is a revolutionary situation at hand: 
There is a feeling around

Of all forgotten possibilities

I maybe can state

This feeling is revolutionary

The world is bad

You got to take a stand against most of it

Capitalism

Has to be pulled up by the roots

There is also a musical dialectic at work, as the hardcore lyrics are performed in a cool and relaxed way with a background of soft jazz music. The group Gunder Hägg/Blå Tåget had a high-brow intellectual background and produced quite a few songs with a central theoretical concept. Ner med allt! (Down with everything) names itself "the gospel of nihilism," I hajars djupa vatten (In the sharks' deep waters) consists of dialogues between different ideological positions. Kerenskjis klagan (Kerenskij's lament) discusses the weaknesses of liberalism in a society of harsh class antagonisms.

\section{Militarism, War, Vietnam, and the USA}

A strong enactment of opposition to authority was to resist compulsory military service. Since 1902, Sweden had a system that meant that young men had to go through military training for one year and then be prepared to be drafted in case of war or international tensions. Conscientious objectors could avoid combatant service on religious grounds. However, resisting military service was related to not living up to your responsibilities as citizen. This resistance could harm your civil career and even lead to prison. Pacifist arguments were largely swept away by cold war emotions against the Soviet Union; however, in the mid-1960s young people raised the ethical question of having to learn to kill and questioned war as a means of solving conflicts. In doing so, they rejected nationalistic and patriotic ideas of the turn of the century, ideas which were still present in public rhetoric and symbols. In early 1965 , young artist Jarl Hammarberg had a sheet with the text "Refuse to kill-refuse military service" confiscated by police at an exhibition and was prosecuted for incitement to rebellion. During the following years, refusing military service became an act that could signify several meanings: a stand against militarism and war, a political act against the Swedish class society, an individual pacifism, or a sign of opposition to the older generation in youth culture. In Brottstycket (Fragment; literally, crime piece), a young man in court presents arguments against military service. Singer Hawkey Franzén made

a concept album with songs he wrote in prison. Many of the songs involved a more general critique of war, nationalism, and the Swedish army.

However, this pacifist rhetoric became the subject of critique from left-wing positions. The basis of the critique was the issue of liberation movements. The NLF in Vietnam fought the US Army as a result of a historical process where democratic elections had been stopped by military dictators. Liberation movements fighting rulers, dictators, and military juntas in situations where non-violent actions were met with violent terror could not be compared with the violence of aggressors. Parallels were drawn to the Norwegian resistance against Nazi German occupation during World War II, which counted as a similar example of how armed struggle would be justified in some situations. Therefore, slogans of peace suggesting that both sides lay down their arms became less credible because they did 
not distinguish between aggressors and defenders and oppressors and oppressed.This problem was discussed in Hoola Bandoola Band's Fred (Peace): "Is it really peace we want? No matter the price? Are we really sure war is the worst option?" The song continues with a depiction of oppression and torture in a military state. Fickteaterns Vi valde inte valdet was an answer to a critique of the NLF's refusal to lay down arms.

We didn't choose violence, it was chosen for us

When others use violence we have the right to fight

What do you want us to do, as the state of the world is now

Punish imperialism with UN resolutions?

We didn't choose bombs, they were chosen for us

When others use bombs we have the right to fight

What do you want us to do when the houses burn down

Stand along quiet and wait for more?

The song also addressed violence at anti-war demonstrations and was one of the songs used in the FNL-rörelsen (the movement for support of the NLF, National Liberation Front, in Vietnam). This movement became the most significant and attractive movement of the young generation; it was despised by all political parties at the beginning, including the old Communist Party. Through its persistent agitation (confrontations during demonstrations were soon avoided, as it worked more in terms of everyday conversations), however, a huge popular support grew. The movement organized its own vocal groups and spread songs within the movement: translations of American songs of protest like Tom Paxton's Lyndon Johnson told the nation, the odd Vietnamese song such as NLF:s official hymn Befria Södern (Liberate the South), but mostly original songs. These songs formed the tracks in a series of LP albums that were primarily used within the movement, but some songs also got spread by individual artists and groups in other contexts. The chant "Ho, Ho, Ho Chi Minh" used at demonstrations became a song-and-drum track on International Harvester's 1968 album. Fickteatern's En vietnamesisk bonde (A Vietnamese peasant) is an ideal-type narrative of popular resistance: a peasant sacrifices his life in an attack on a military base. Gunder Hägg's Kalla kriget (the Cold war) is an eight-minute song version of David Horowitz's book From Jalta to Vietnam, a history of US foreign policy after WWII in which the US takes over from former European colonial governments. The song ends with the words: "The Vietnam question is a simple issue: you ask who has the right to be there."

US foreign policy was scrutinized, not only as the cause of the Vietnam war, but also as a systematic policy to rule the Western world, to keep the iron curtain closed and to stop Soviet and Chinese influence in Africa and Latin America. Atlantic Ocean's collage-like piece United Fruit begins with an interview in Spanish on the subject of US economic and political dominance in Latin America, and then turns to a choir chanting the name of an American company with huge interests in fruit production and exports. There is also an English voice-over that revels in all the natural resources available for exploitation. The dominance of Latin America included direct military invasions to overthrow governments or support to military juntas that took charge in order to favour US investments and companies. The military coupe in Chile in 1973, when social democrat president Salvador Allende was murdered along with thousands of civilians, infuriated many Swedes. 
There was also a strong critique of US internal policy and different traits of American culture and history; this probably was a backlash against the very positive image of the USA that had influenced Swedish popular culture since the late-nineteenth century. The USA as a democratic model, an idea strongly promoted during the fifties, lost much of its credibility with the murders of John F Kennedy, Martin Luther King, and Robert Kennedy. Gunder Hägg's Tio svarta pantrar (Ten black panthers) comments on the persecution of black militant organisations. Peter Mosskin's Ohio 4 maj 1970 was written amidst the despair of the four students who were killed at a Kent State University demonstration. Further, quite a few US citizens came to Sweden as immigrants or as deserters. Peter Mosskin's John Babcock poses questions of the deserters' liminal social status in Sweden, while Västerns son (Son of the West; Contact, co-written with Hollywood record producer Kim Fowley) represents the longings of sons and their parents.

\section{A Reflexive Left-wing on the March}

As mentioned above, slogans and chants from demonstrations could be made into music piecesand vice versa. When people climbed the elms in a central park in order to stop them from being cut down in Stockholm in May 1971, the contemporary John Lennon/Plastic Ono Band song Power to the People was turned into Almarna at folket, "The elms to the People." This spontaneous chant was then developed into a full song lyric by the group Envoys. Some songs such as Turid's Going to prison, reflect on demonstrators who were arrested by the police-a possible Swedish parallel to Malvinda Reynolds' It isn't nice. However, there was also some self-criticism. Ted Ström discusses the commercialization of Che Guevara in Våra hjältar (Our heroes):

Men who died in struggle for the people's rights

Pacified into fold-out objects

We easily fall for the myth of the hero dying in combat

And conveniently forget what originally disturbed the peace

Che Guevara just as Christ passed away

They are surrounded by a peculiar, mixed haze

Their spirits are said to live on

Tell me, who is on your bedroom wall?

Gudibrallan was a group that did not stop at poking fun at the deadly serious left-wing attitude in songs such as Intelektell ("Intelectal”). Hoola Bandoola Band's Burrhuvet (Buzz head) is a critique of the people who speak radically, but do nothing in practice. It speaks of someone who always is putting down others in private-an attitude that must have been an internal problem for a movement trying to keep together.

\section{Escapism, Drugs, and Social Problems}

The lifestyle of political consciousness and activism had its competitors or deviancies. Verklighetsflykt (escape from reality) was a word that was used to signify the distance to attitudes and artistic expressions that lead people astray, that is, it distracted their focus from important issues and was 
aimed at the idea of individual rather than collective pleasure. The liberal and romantic view of drugs that came forward in the popular culture of the mid-1960s, and especially rock music, was something that should be acted against because of its escapist attitude and pacifying effects. Singing realistically about drug addicts and other social outcasts could be a warning, as well as a protest against society. In Margareta Rosén, Ted Ström meets an old school mate-once a teenage school queen, but now a desperate drug addict and dealer. In other words, the short duration of superficial social appreciation is in focus. In Ström's Anders Jansson, nyckelbarn (latch-key child), however, it is the fostering and working conditions that starts a mechanism of social exclusion, in which drugs and criminality are merely the outer signs of a sick society. In En efter en (One by one; by Leif Nylén of Blå Tåget for Marie Selander) there is a series of different mechanisms: a stressful working pace and the threat of factory closures, criminality, drugs, or the middle class fright of "the suction from the bottom and the threat from the top." Singing of drug addicts could also be an act of sympathy: to speak on behalf of sensitive individuals who fare badly in a cold society. Sogmusobil's Arabic in the morning shows images from a mental hospital; it is dedicated to a number of named musicians who were treated badly and died young. Quite a few songs deal with criminals, using the question "how was I/he made a criminal?" This coincided with a tendency to introduce the ideas of rehabilitation programmes. A few ex-convicts made definite breaks with criminality and established themselves in society—some became class conscious political activists and/or artists. An album of prisoners' songs established one of the singers as folk song artist, who largely performed autobiographical songs (see Svensson 2001).

\section{Ego, Life, Emotions-Fright, Anxiety, Nearness, Doubt . . .}

Many songs deal with the development of the individual and can be seen as ways to form and express an ego: Thomas Wiehe's Misstro (Doubt), Risken finns' Jag (I), Solen skiner's Jag vill leva (I want to live). At one level there is a kind of collective self-image among the young leftists that is about "waking up." His awakening involves looking at society and existence in a more critical way. This increase in political interest is understood in terms of a collective generational experience. The political

awakening is seen as an important step in an individual process of maturation. The change can be from the idea of an idyllic childhood that is accomplished through a school that supplies an image of the conflict-free welfare society_raising kids to become obedient citizens-to an independent, socially and politically conscious individual. Peter Mosskin's Lingonrevolutionen (Mountain cranberry revolution) speaks of a happy childhood in terms of a long summer vacation with sunshine, ice cream, hugs, and berry-picking; but then he changes the perspective:

That's not how it was

The headmaster was no father

School wasn't a loving mother

Christian Diesen's En förfragan (An Inquiry, for album Tillsammans) poses existential questions but then changes the focus:

At first, I thought the answer to my question

Was that man is evil

Then I understood, that is exactly

What the machinery of power wants us to believe 
This awakening is also represented as an imperative. Some songs take the form of conversations or disputes with old friends who have not understood, and who refuse to see reality as it is. They are stuck in old, conventional ways of thinking. Mikael Wiehe returns several times to this theme in such songs as Ingenting förändras av sig själv (Nothing changes by itself), which is the definite breaking up of a friendship, or in Man måste veta (You got to know) that ends with the lines: "Soon the train is coming, you said you wanted to join/But if you don't come now, you will come too late." The courage to dare also is a recurrent topic. One example is Fickteatern's Frågor (Questions) where the refrain closes with: "The strongest human in the world is you, and/The strongest word in the world is NO!"

Ta hand om ditt liv (Take care of your life) is one title from Solen Skiner. In the Narren theatre's Strejkvisan (Strike song) a young journalist says farewell to her fiancée after having become politically aware through her coverage of the great miners' strike in 1969-70. However, political awareness did not necessarily mean a strong and independent individual ego. Identifying oneself as a worker, or as an intellectual serving the masses, or as a socialist who takes part in the fight for a better future, were distinct positions. However, there were also people who did not have a definite class affiliation. This was an age of class mobility, and many young people had not made their final choices concerning their positions in society. Many were caught doubting the political potential of the own middle class existence or caught outside of the contexts where the socialist struggle was happening. The existence of organizations and causes was presupposed by activists and gave the individual the idea that they were both committed and needed. Kjell Höglund wrote, "We are the outcasts from politics, we have been pushed away from the barricades" (Politikens olycksbarn"). Höglund and Ola Magnell were the two singers who most effectively gave shape to the insecure self-image-a reasonable consequence of a social consciousness and a social change where old roles were no longer valid. The relation between the personal and the political was often addressed by Lasse Tennander. In Alla är vi barn i början (Everybody starts as a child; proverbial saying) and in Rädd att flyga (fear of flying), he highlights qualities such as "patience, knowledge, and humility" and the courage to acknowledge your fright and anxiety, which are then used to counter the presumptuous revolutionary ideals that prevailed.

\section{Ego and Relations}

An important question when it came to creating distance from commercial music was how to sing about love. The moon-June lyrics were the antithesis as they contained stereotyped images and cultivated an obsolete image of romantic love. The radio hit parade show Svensktoppen (Swedish Top) and, for the most part, the commercial music industry were seen as distributors of dishonest romance. Nevertheless, love is an important and recurrent theme in my sample. This may be surprising if the starting point is that "love" is something private in contradiction to the collective and political. However, one of the slogans of the 1970s was actually "the private is political," which could be interpreted in several different ways. One interpretation focused on how the subordination of women is constructed by the image of romantic love, conveying an ideal way of living, where falling in love and marriage are the only important goals. A further interpretation was the aspiration to authenticity in selfapprehension and in relation to others, which is possible to interpret as a political goal. This

\footnotetext{
${ }^{9}$ This title refers to a novel by Victor Hugo. A relevant translation would be Les Misérables of politics.
} 
interpretation makes love an important theme for youth singing and writing-a whole being, conscious of personal feelings and emotions as well as of injustice in society. However, love became a problem when confronted with an (imagined) politically conscious audience, especially as an isolated issue. It was possible to sing of love with a personal engagement that began with your own emotions, if you could avoid stock phrases. What about singing of love in general? Norrbottens Järn's Jag och Du (You and I) speaks of love between people, who are "everyday people," with a slowly rising political consciousness as a common sounding board. Lasse Tennanders Tillsammans (Together) puts the lovers into a common struggle that is explained on the album cover: “Tillsammans' isn't just about a relation between two persons, but also about the common struggles we participate in.” Suzanne Osten's and Louise Waldén's Också $d u$ (You also) verbalizes a lovers' relation based on equality—written for the feminist album Sanger om kvinnor (Songs onWomen).

The positive love song contains traits reminiscent of what sociologist Anthony Giddens (1992) names confluent love: friendship, support, comfort-longing-to feel complete. This confluent love, a late modern phenomenon, is contrasted with romantic love by Giddens. However, songs of love between comrades may not fall into the period of late modern ideas, but could also be a lingering ideal of the labour movement of the 1930s where the conscious position is superimposed on an un-reflected biological gender polarity. For socialists, individuality is subordinated to the membership of the collective, and comrades in the movement are supposed to want to have a family.

Otherwise, love was expressed in terms of hesitation, doubt, sorrow over broken relations, or longing that was considered to be authentic. Here the private could become entangled with the public and political: society, conventional ideas of upbringing, traditional gender roles and so on are put up as obstacles to the authentic reciprocal love. This is clearer in songs where love is spoken of from a third person perspective.

An understanding of mass media images of romantic love as stereotyped and distorted is the theme of many songs, such as Den stora maskeraden (The great masquerade, by Hem igen), Prinsen och prinsessan (The prince and the princess, by Norrbottens järn), Romeo (by Dimmornas Bro), Drömmar om sagoslott (Dreams of fairy tale castles, Löpande Bandet). Sexuality and gendered power among youth, or who is considered a conqueror and who a whore, is a theme that is addressed in theatre plays as well as odd songs. Feminist group Röda bönor often addressed sexual politics, on an individual as well as a legislative level. For example, their Sexualbrottsutredningen comments on the parliamentary committee in charge of sex crime issues and its definition of what counts as rape. The public preoccupation with sexuality issues (in the tabloid press and weekly magazines) and its construction of expectations that affect individuals was commented on by Lars Aldman in Den fulländade älskaren (The perfect lover), Risken Finns' Sexualdebatten (Sex debate), and Tjejlaten (girl tune), in which the boys leave a space for a girl to sing in first person.

There are also a number of alternate images of love. The NJA group's När han kommer hem (When he comes home) is a worker woman's song of her love for her man, mixed with her anxiety over his dangerous working conditions. The same group, but with the new name Fria Proteatern, wrote several similar songs of class/comradeship love. Fickteatern's Ett brev (A letter) tells of political activists:

The man they shot in bed in Chicago

Lies in our bed when we get up

The boy they shot there at a corner 
Is our son, the son we never had

The anxiety which is mine you carry in your heart

You turn pale by the beats of my heart

Frightened we both go into the cold

No-one wishes what happens. . .

Now, we are many in a sea of hate

I leave these words with you, my loved,

In confusion, by a younger lawyer

I hope, if you are the first one to fall

You have put a letter for me somewhere

Even the heterosexual norm was beginning to be questioned, but with rather few examples like Stefan Demert's Bertil och Sven (Bertil and Sven), Jan Hammarlund's Jag sa Christer, du är galen (I said Christer, you're crazy), and Sexualpolitiskt snack (Rap on sexual politics).

\section{Gender orders and women's issues}

The 1971 LP album Sanger om kvinnor (actually a 1972 Grammy award winner), was made by a collective from a second wave feminism-pioneer organisation Grupp 8, and repeatedly has been considered important in the Swedish Women's Lib movement. It introduced songs that became icons for the movement, such as Vi är manga (We are many, we are half of the population) and the definite theme Åå tjejer (Oh girls, we have to raise our voices to be heard). The new feminism was (at least up to 1975) primarily understood as a socialist endeavour, as indicated by the slogan Kvinnokamp-klasskamp (Women's struggle—class struggle). On the Sånger om Kvinnor cover stood the words: "Boys, don't be afraid! We're gonna smash capitalism, but we only want to change you!" Thus, many songs deal with the question of women's conditions, which is a subordinated issue in the class oppression that men and women share. Hoola Bandoola Band's På väg (Going ahead) is a combined socialist/feminist anthem. Individual portraits of worker women and their working conditions are quite abundant_Löpande Bandet's En kvinna bland alla andra (A woman among all others), Kurres Kapell's Elsa, Bättre lyss Emma, Jan Hammarlund's Sofia, Nationalteatern's Hanna från Arlöv, Marie Selander: Linnesång, Vargavinter: Lowell Factory girl, Hemväverskan, Washwoman's blues, Störningen Maria Antonia, and Lovart Sång från en skurhink (song from a scouring bucket). Other songs address conventional gendered roles and relations: Peps'Vakna Törnrosa (Wake up sleeping beauty, slap the prince between the eyes), Björn Afzelius' Kvinnoförakt (contempt for women), Jan Hammarlund's Jag hatar patriarkatet (I hate patriarchy), Musikteatergruppen Oktober's Till Alexandra K (also recorded by Nannie Porres), and Turid's Javisst går det an (of course it's possible-named after a pioneering 1838 novel on gender equality). Gröt och banderoller (porridge and banderols) by Christian Diesen includes irony aimed at left-wing activists' reproduction of traditional gender patterns:

Now she sews red banderols

For a revolutionary

Makes porridge and satisfies his needs

Raises his children

Together they fight for

Class consciousness 
Sometimes the working class perspective promoted the reproduction of traditional roles, as in Nynningen's Balladen om servitrisen och flyktingen (Ballad of the barmaid and the refugee) where a Swedish barmaid falls in love with a Latin American political refugee:

For someone like that,

It feels so fine

To open your door

And your arms at the same time

Or in Höj rösten's När man kör en Scania Vabis, where the truck driver sings:

You think about your wife

You know she is strong

But she can't make it alone

You have to manage more

In the collective album Tjejclown from 1974, femininity is questioned in terms of it being a role to live up to (Kvinnomatten, women's measures), a form of subordination in a love relation (Sista saingen punkt slut, Last song, period, end) and as a norm in society (Knäpp gylfen Freud, close your fly, Freud). Masculinity is taken up in Text \& Musik's Farsan (Dad) and Grabbarnas grabb (Guy of guys) and Störningen's Klavertrampens häxmästare (Warlock of embarrassments). Arbete \& Fritid's Se upp för livet (Watch out for life) is a double album on masculinity and produced together with writer/artist Ulf Lauthers for an art exhibition.

\section{Youth, Parents, Kids}

A sceptical youth perspective on society was strongly promoted around 1970. The distrust of the school system and mass media representations of the young generation is present in some songs by Peter Mosskin, who, together with wife Louise, had made a book of interviews aptly titled The Youth Revolt (Ungdomsupproret, 1969). In Vad ska vi göra? (what can we do?), he gives voice to the young suburban proletariat who hang around in underground stations and shopping malls, unwanted, harassed by guardsmen - an image that became popular when rock bands tried to reach out to worker youth. Det måste kännas taskigt att se mig gå (It must take you bad to see me go) is aimed at the older generation and serves as a kind of last word in a dialogue that time after time has exposed the older ones' inability to understand. Långhåriga saker (Long-haired things) expresses a youth subjectivity starting with what "they" describe as today's youth: "They call us long-haired things." Jan Hammarlund also positions conflict in school and with parents into words in his first albums: Befriade från skolan (Freed from school) was the title track of his first album, Barnet som dom lämnade på vägen (I am the child they left along the road) was on the second. Turid's Personligt brev (Personal letter) and På din motorcykel (On your motorcycle) consist of a grown up woman's intensive attempts to find a way to communicate with her parents (her songs are analysed in Ganetz 1997).

Pugh Rogefeldt's Föräldralåten (Parent tune) has a more tongue-in-cheek attitude and was a rather big hit in 1970: 
I'm 18 years old, and my mom always interferes with my love affairs . . .

Hey mama, keep your big mouth shut, keep your big mouth shut ${ }^{10}$

My dad has lost all his dreams...

I dream away when the world seems horrible with wars and decadence . . .

then my dad comes along, 'you'll get along, just you do your military service

and grow up to be a man'...

hey papa, keep your big mouth shut, keep your big mouth shut

Then, during the late 1970s, a position as parent starts to form. Lasse Tennander devotes several songs on his third album to his new-born son. Marie Bergman, Slim Lidén, and others sang about how to combine being a parent with political consciousness. Songs from parents to children also are used in a more symbolic ways, as a means to express resistance and hope for the future-such as Turid's Vakna, mitt barn (Wake up, my child) and Moder (Mother), or Höj Rösten's Vaggvisa (Lullaby).

\section{Alienation, Loneliness, Community, Communication}

The concept of alienation started to be important in the intellectual discussions of the 1960s, and was referred to as a problem of capitalist society. In songs this is directly addressed, represented as a lack of communication, or as a sense that life is without meaning:

You have a paper face

And your eyes are like lead

When the night comes to an end

Where your dreams are worn out

Don't think the arriving day

Is yours

(Vildkaktus, Dagen som kommer, The arriving day)

Blå Tåget had several songs on the subject and one song was actually called Alienation. Slowfox depicts how the late modern society promotes images of how life could be, but then the images are dashed:

Lisa dreamt of a luxury life

She worked at an office

One day she got her chance with Mr Grant and said

Fare-well to ma and pa

And love strikes a wonderful night

It burns intensively in a shabby hotel

Your dreams vanish in smoke, your flame is put out

When the grey of the day wakes you up

Jan Hammarlund also uses the alienation concept in his first albums. In songs like Slottet (The castle, 1972) and När kan vi dela (When can we share, 1973) he points to the loneliness and lack of solidarity in contemporary (capitalist) society and contrasts contemporary alienation to the solidarity and

\footnotetext{
${ }^{10}$ This line is sung in English; it is probably taken from a Bo Diddley song showcased by the British group the Pretty Things in 1964.
} 
fellowship in a society to come. Sitt ner och sjung en sång (Sit down and sing a song, 1972) is a low-key party song for those who choose to reject society and live in hope of a better one. Solen skiner's Vissla $i$ mörker (Whistling in the dark) jumbles images of meaninglessness on each other. Likewise, Eldkvarn's En lång het weekend (A long hot weekend) and Peps Persson's Babylon are dominated by the emptiness of existence. Solen skiner expresses in Min tystnad (My silence):

I know I live but I show nothing

I know I think but I say nothing...

To lick the arse of decency is not a way to live

When the hidden scream of revolt tears my body

A significant counterargument against alienation is sometimes associated with a position in which one can "see through." That is, one can see through the superficialities of society and existence. In Vildkaktus' Men jag har sett (But I have seen) this is represented in a minimal way by contrasting the ego with the individuals of the anonymous mass:

All day long is a sad dream

Identical people in an endless stream

Their faces all look the same

And they always think the same of right and wrong

The average men look around

They are looking but never find anything

But I have seen

But I have seen

To "see through" could result in several attitudes: a political critique of capitalism as the underlying system that rules people, while at the same time making itself invisible; or a more buddhisminfluenced attitude where the real values of the existence are not in the material world; or a combination of the two (Hoola Bandoola Band's Maya uses Buddhist metaphors to speak of illusions in our society). Träd, Gräs \& Stenar's Sanningens Silverflod (The silver river of truth) sings lyrically of the utopian existence by the river of truth, but ends with a spoken rhyme to the members of parliament who do not see how their world is ruled from the USA. The metaphor of awakening is often used, as in Solar Plexus' Sagorna (The Fairy Tales), Lasse Tennander's Sagorna är slut (No more fairy tales), Andreas Aarflot's Morgongåva (Morning gift), Elektriska Linden's: Uppvaknande (Awakening), and Marie Bergman's God morgon (good morning).

Alienation also is connected to lack of communication. Gunder Hägg's first two albums deal with alienation as well as language. Alienation is the title of one of the songs, and the word is repeated like a mantra over a 12-bar blues structure. Jag har sett det förr (I've seen it before) speaks of language and its significance in society and existence: "Nothing seems to change. It's the same old play with words, the same roads, the same structure on our earth . . . a conversation demands content, but the content of language turns into a logical ball ..." and (in the last stanza) "Something is starting to change. At a distance from language I see more, I can shout: It isn’t words I see!” Teddy Bear Baby and Låt mig få leva (Let me live) have nonsense lyrics where stock phrases are piled upon each other.

The importance of communication, linguistic, and other forms of interpersonal communication, is stressed in Kebnekajse's Kommunicera (Communicate). The title turns into a rhythmic hook. In their 
song Tänk på livet (Think about life), the following lines can be heard: "Think about life, think about what you do, think about life, bear in mind to do, something that means something, to someone who means something to you."

Loneliness is a rather common theme. However, in order to delve deeper than just the individual feeling (images of an ego expressing loneliness and longings), loneliness is associated with society: What in society makes people feel lonesome? Why are there no social contacts that match people's need for community? How does the organisation of society put obstacles in the way? Love explosion's Djävulens patrask (The devil's riff-raff) show images of social exclusion, fright, and estrangement: "who turns us into strangers to each other, yes, it's the devil's riff-raff." Nationalteatern's Ut i kylan (Out in the cold) speak of a teenager kicked out of the communal youth centre:

If we had our own place

Where we could look after each other

And not kick each other out with ice cold rules

One of the winning sides of the Hoola Bandoola Band was their ability to express a positive image of community as a reliable "we" that included all the progressive forces, all the oppressed and the subordinated-an image that took the shape of a mighty tidal wave that could shake the society. The song $P a ̊$ väg (On the way) bind men and women together in performance and in lyrics. Another song, Rocksamba, stresses that there is also room for insecure people with low self-esteem and solidarity: "We have the fairy tales on our side just because we are small/With some help to interpret the wording it's easier to understand."

\section{Mass Media, Commercialized Culture, Music}

In the early 1960s, television appeared almost overnight. Regular broadcasting started in 1956 in the city regions, and by 1960 all parts of the country could see TV. Almost every household bought a set immediately, thus making one channel a common experience for all and the number one supplier of news and reality. Other media turned their interests to TV, even making news anchors into pop stars (although the board disliked this and actually sacked those who did not keep a high-brow profile). After the initial fascination, a large wave of media critique came in the mid-1960s. The FNL-grupperna pointed out that the reports on the war in Vietnam were often tendentious. Poet Göran Palm wrote an influential book, Indoktrineringen $i$ Sverige (Indoctrination in Sweden, 1968) where he pointed out how mass media functioned as a guardian of the existing national and international order.

There were sometimes comments in songs on Sveriges Radio (Sweden's Radio) as an institution and on its specific policy, but it is first and foremost the flow of images and individuals in mass media that emerge in songs. Gunder Hägg sings in Bröderna Surf (Surf Brothers) of a TV trio who made rather hollow comments on contemporary politics, and project them as symbols of mass media in general. The title compares them to a soap brand. Peter Mosskin in Mellan vatten och land (Between water and land) presents a long row of mass media personalities in a Dylanesque way (including Dylan, who is absent"he's gone to desolation row"). The introduction, "I sit on a bridge between water and land, I no longer know land from land" involves the idea of being lost in modern society. A similar structure appears in Hoola Bandoola Band's Vem kan man lita på? (Who can you trust?) where mass media icons are exposed 
for not living up to their myths; similar songs are Tillsammans' En förfrågan (A questioning) and Mobben’s Tåglåten (Train tune), Turid's Du krökar dig väl yr (Sure you get drunk), Mobben's Flykten från Mekong (Escape from Mekong), Pugh's Slavsång (Slave song), Sten Bergman's Lyckohjulet, (Wheel of fortune), Norrbottens Järn's Drömmarnas värld (World of dreams), Ted Ström's Livet går vidare (life goes on), and Störningen's Jag och min kompis (Me and my pal). Olle opolitisk (Olle unpolitical) by Rekyl and Riskens Finns' Jag vill bli underhallen (Entertain me) include irony that is directed towards fellow young people who unsuspectingly take on the role of consumers and do not want to speak of politics. Commercial entertainment could also be described as a desperate search for joy with its origin in social alienation and a lack of meaning in life. There are some depraved cafés and dance halls depicted: Skuggornas kafé (Café of shadows, Ted Ström) and Club Husar (Love explosion). The rather shabby café with all kinds of unlikely characters is a recurring setting in Blå Tåget’s songs such as Café Europa.

The commercial production of music as goods was heavily criticized, but more often in manifestos and debate articles than in songs. Pugh Rogefeldt set music to Bertolt Brecht's description of the artist's existence in Hollywood: "In order to make my bread and butter / I go to the market where they trade in lies."

The decline of rock music as it became more and more commercialized in the 1970s was criticized by Norrbottens Järn in Sune Violent and the Glassbreakers and by Risken Finns in Självkritik I (Selfcriticism 1):

(Come... Now the REVOLUTIONARY musicians start . . . oh look, Alice, Alice, Oooohhh!

Alice Cooper hangs himself on stage ...

So EXCEPTIONAL . . . UNBELIEVABLE . . RADICAL!!!

When you paint your face, your ears and neck

Fight and raise Cain on the scene

In Entertainment by Solen skiner, a singer complains over his failure to become famous by imitating the styles of James Dean and Bryan Ferry: "I got the entertainment blues." Instead, a positive role model that often was put forward was the fiddler of Swedish folk music, a romantic image that had been around since the nineteenth century and reproduced in Growing Grass's Folklaten (The folk tune) and Splash's Spelmannen och forskarlen (The fiddler and the water spirit). In Contact's Grannlaten (Neighbourhood tune) folk fiddling was introduced as a contemporary alternative (the group actually became a success by combining rock and folk):

Summer night, fiddle sounds call to dance

Felt the heat of the girl's arm around my neck

The whole village came together after daily work ...

Where is the sound of fiddles and laughter

Nothing is made to brighten our suburban night

Deep within a protest takes form

Open the door, invite your neighbour to a party

Thomas Wiehe's En dansmelodi (A dance melody) achieved an almost programmatic position in expressing the characteristics of the Good Music. The following lines became a slogan on the cover of 
the first issues of movement magazine Musikens Makt (The Power of Music): "String your fiddle, grab your horn/We shall build the everyone's music culture."

Bengt Eriksson's Gärdet 1970 sums up the emotions surrounding the first and heavily influential free festivals at Gärdet in Stockholm:

When I play guitar, it sounds like I'm chopping wood

When I sing it's worse than the croaking of the crow

But it is beautiful, yes it's beautiful,

Because it's me, it's you, it's we, all together

A theme of reflexivity in the writing of songs is also evident, as in Bernt Staf's Stadsvaka: "I wander around, thinking of an ode/On big companies, military and fag." Other examples include Fred Åkerström's Vissångarvisa (Songsinger-song):

But who pays a heavy price for my success and my song?

It's people fighting against starvation in their countries

While I walk around belly-fat and burp you a song

About Spain, Belfast, Greece, and Vietnam

And Lasse Tennander's autobiographical På jakt 1 (Out hunting 1), which concludes with a series of questions:

Can I be so sure I'll stand by my words?

Can I say tomorrow that my hunt ended here?

Have I lastly and forever arrived back home?

Or am I just out to get my picture on the cover of the Musikens Makt?

The last reference to the progressive music movement is not the only one. Greg FitzPatrick's Befria Norden (Free the North) is a 1977 medley of movement "oldies," and in Lars Fernebring's Progressiva texter (Progressive lyrics), there is also a critique of the routine lyrics of a movement stuck in a rut. In a Musikens Makt article ("Where are all the lyricists with brave new ideas?" issue 10, 1977 ), he presents similar thoughts:

Today it seems like every proper prog record has to consist of a kind of catalogue of problems. One song on correctional treatment for criminals, one of factories closing down, one on women's lib etc. Check and add! ... The form I think gives the best effect for those who listen. That we understand and recognise each other's experiences and reactions. My lyrics are about those who sit in the audience. About us. Who else should they be about in order to be important?

\section{Religion}

The rise of leftist thought was also influential in the Swedish State Church. To take a stand against racism and oppression, to work for a more just relation between Western and Third World countries, and to protest against war and rearmament was easily motivated through the central message of Christianity. However, the church was a symbol of the old society, the old belief in authorities and old 
superstition as a technology of domination. To question the dogmas of Christianity was one way to question the power structures in society and also idealist or materialist philosophy. The group Gudibrallan (God in pants) tested the borders of blasphemy through their very name (as late as 1964, a comic was sentenced for a radio joke about drive-in communions), as well as in their song Hej Gud (Hey God), a reworking of Jimi Hendrix' hit "Hey Joe." The song consists of a slow section where the line "Hey God, why do you stand there with your pants down"11 is chanted on and on, and a fast section where absolution is given to historical and contemporary politicians: "Hey Nixon, I forgive thee thy sins; Hey Palme; Mao, Hitler; Stalin,” and so on. The same year, 1970, Gunder Hägg came up with an effective chorus in a song primarily about late nineteenth century European colonialism and imperialism where the Christian missionary cause served as a legitimizing argument: "God is conspicuous in his absence, he was rather dead than red." In their song Creation, ${ }^{12}$ the group Fruit alternated between verses that retold the beginning of Genesis with a recurring chorus stating: "Lies, all these lies, only lies, to the world." Christian Diesen also presented a critique of religion in Söner frågar fäder (Sons ask fathers):

I doubt a saviour

I don't believe in solace

I am no hypocrite

With a cross on my chest

I distrust religion

With its metaphysics

I repudiate the missionary work

And the mystery of spirits

Sons ask fathers

Why do you let me die?

Göran Persson depicts conservative vicars who do not understand that their authority is on the wane, in Präst och general (Priest and general):

When I stand in my pulpit

And look down on an empty church

I can't understand those who don't turn up

What could there be of interest outside the church?

Blå Tåget returned to the topic in 1974 with Hälsa Gud, a dialogue between the ego and a priest, where the latter's claims of an almighty God who rules everything are refuted: "Tell God they have a feast on his son, and that his heaven is a heaven bombs are falling from." Other discussions and doubts of Christianity are found in Thomas Wiehe's Bilderna av fakiren (Pictures of the fakir): "Mama, I started having nightmares, since we started having religious class ...” or Sten Bergman's Människofiskare (Fishing for humans). However, the image and message of Christ is also used in a leftist critique in songs as Contact's Guldkalven (Golden Calf) and Growing Grass' Sista budet (the Last Commandment).

There was clearly a competition for ideological influence, that was not only reflected in the criticism of the churches and priests, but also by rival ideas and attitudes as well: the inward attitudes

${ }^{11}$ The expression to be caught with your pants down usually means to be exposed as a hypocrite, bluff, fraud.

${ }^{12}$ Song in English, 1971 (radio show); when making an album in Swedish 1974, the song had a completely different topic. What was thought of in terms of a heavy statement in 1971, was irrelevant in 1974. 
behind New Age_philosophies, meditation, and smoking pot (Lars Aldman's Livets mening, "Meaning of Life," Risken Finns' Självkritik 1,2, "Self-criticism 1,2") and the superficiality of contemporary "unpolitical” commercial youth culture (Risken Finns's Jag vill bli underhållen, "I wanna be entertained," Rekyl's Olle opolitisk, “Ole unpolitical,” Norrbottens Järn's Discofank, and Anton Swedbergs' Disco-Dick). Norrbottens Järn's Diskoplast och hippievadd (Disco plastic and hippie wool) hit at both targets. Turid's Stjärnor och änglar (Stars and angels) also stamped out theory-obsessed leftism.

\section{Songs in a Changing Society}

The sentiments that are expressed in these songs have many similarities at an international level. The youth, student, women's liberation, and environmental movements were founded and developed more or less simultaneously in the Western world. However, many of the issues and examples that have been taken up in this article do refer to a reality that is Swedish. The specific Swedish experience of growing up in a country that claimed that the workers' movements were in charge, and tried to build a middle road to socialism, meant that the labour movement became the focus of critique. Not only did the Swedish left deal with issues concerning the exposition of capitalism, but also had to deal with the shortcomings of the social democrats, who were accused of betraying ideals and naively trust in reforms. At the same time, the building of the welfare state was just beginning. This social change involved the expansion of the public sector, which meant that many young educated people began building state and municipality organizations as teachers, doctors, and social workers. Many of theses people had worker family backgrounds. This formed a new social group, whose everyday practice was working towards changing the old and unjust society into a kind of "soft" socialism, or at least realizing the ideas of the French revolution.

What is the significance of all these issues for the importance and validity for song lyrics? A comparison can be made with a study in political science by professors Ulf Bjereld and Marie Demker on the "1968 revolt against authorities" in Sweden. In their analysis, the tearing down of old authoritarian structures is of central importance; they regard 1968 as a "total break-through for modernity" (2005:19), but also as the beginning of the formation of central social groups in the emergence of the information society.

In their analysis they point out 14 areas of particular importance for the revolt against authority: Family, Public morals, Patriarchy; Art, Sports, Church, School; Monarchy, Military, Parliament and international order; Employers, Work, and Capital. Their survey is important because it shows how opinions and actions in many diverse areas can be perceived as being linked to each other. A comparison with my results shows a rather high concordance. Interestingly, Public Morals, that is, new attitudes to sexuality, are not considered to be that important. This is probably due to the fact that this issue was a topic of debate in the mid-1960s, which was just before the period of the study. Instead, there are songs that deal with the new, "post-free sex" problems of gender structures in sexuality. Sports was definitely one area where old authoritarian attitudes were changing, but this was mainly due to the indirect effects of freer pedagogy and new perspectives on youth. Apart from the occasions where sports could focus on other phenomena, this was not of particular interest to leftists, Hoola Bandoola Band's Stoppa matchen (Stop the match—written for the demonstration against the Davis Cup match Sweden—Chile in 1975) and Nationalteatern's Mr John Carlos (on how the Olympic 200m champion was ostracized for having made a Black Power sign at the winner ceremony), are the only examples of songs that had any great 
impact. The Swedish Monarchy, which had little real or potential power for decades, was hardly of any special interest and just considered to be one obsolete institution among others.

However, I do not think "revolt against authorities" is a viable description. There was also a more general questioning and searching, which, in the case of environmental issues, urbanization, critique of consumerism, and social exclusion, created association to questions that undermined the authority of the parliament and the big companies. Further, there was a definite endeavour to build positive alternatives: non-profit clubs and co-operatives, new political organizations, and new subjectivities such as "the new human." These independent and well-informed, yet non-competitive alternatives showed solidarity with others, putting co-operation before the ego.

\section{Construing Subjects and Presenting Actors}

Besides commenting on different topics, song lyrics also present diverse actors and give voice to subjects. A number of stock actors do appear when studying such a large corpus:

- Demonstrating youth

- Youth of the suburbs

- The workers

- Soldiers of a liberation army

- People being oppressed, suffering

- The fighting people

And the antagonists:

- The Bigwigs, "herrarna i höjden" (The masters in the sky)

- Capitalists

- Police men and guardsmen

- The US Army

The voice of the narrator varies in terms of position and address. It is common for the lyrics to have a third person perspective of events, but this voice also comments and evaluates what is happening. A first person perspective is also common: an $I$ that speaks and expresses opinions and emotions. A less frequent, yet also noticeable voice, is the second person "you." This voice could be in a song about a meeting, as in Hoola Bandoola Band's Ingenting förändras av sig själv, in which the "you"-address is the result of a dramatized representation instead of a narrative one. However, some lyrics also refer to the listener as "you." This "you" is often pedagogical or agitating: "what are your conclusions?", "oppose this," "support those who fight," or "stand up for your rights." Sometimes "you" is addressed with an "explain to me," which often is just a rhetorical device for underlining the absurdity of a situation.

The collective "we" is also regularly used, especially in the organization fighting song, whose existence is primarily to constitute a "we" subject. However, the construction of a "we" is also the logical purpose of many songs because there is a process in which the experience of individual hardship is a 
means of becoming aware of the experience's collective dimensions. Hoola Bandoola Band's Andersson $\mathcal{E}$ Co presents one series of individuals with problems, only to change the perspective in the chorus:

But take them together

They form a group

And then you have to seek the explanation somewhere above

And only together

They can take up a fight

To change their conditions

And change their lives

On the Höj rösten album cover, a "we" of solidarity is contrasted with a "they" that tries to pacify:

You know your reality, and know that together we can change it-

the culture of the capital gives us false songs of a reality the masters want us to believe in

In their songs we are powerless, there is nothing but passivity and escapism

But there is a culture among the working people

A culture with songs about the friends at work, about community and professional pride

Songs about solidarity and the fight for better living conditions

More seldom there is a plural "you."13 It could be used in the young people's call to a parent/ grown up generation, as in Nationalteatern's Sveriges styvbarn (Sweden's step-children):

You are well-adapted suburbans...

But now we ask all of you

Won't you come down

And let us work together in

Levelling the shit with the ground

The "you" can also refer to well-adapted ordinary people-the "Svenssons." The message is "wake up, support us, help us, come to the realisation that you are oppressed as well." However, there is also another "you," which refers to antagonists, the enemy—a "you" that could just as well be spoken of as "them," that is, the rulers in charge.

We, we are the people

Who have to struggle every day

We made the fortunes

That were intended for us

We, we are the children

Playing and dancing was for us

But your cold greedy brains

Had made other plans for us

(Löpande bandet, Den sista paradoxen, The last paradox)

\footnotetext{
${ }^{13}$ Swedish uses "du" for second person singular and "ni" for second person plural, making this distinction easier than in English. "Ni" can also be used as a polite or subordinate way to address the second person singular; this used to be the norm in public meetings, "du" only being possible in familiar relations. However, this changed in the late 1960s, when the new director of the Board of Health and Welfare told all his staff to use the "Du" address.
} 
As for the representation of gender, there is a clear dominance of male protagonists and male spheres. The voices that articulate gender are neutral, however, as there is seldom any specific "I'm a young man" form of expression. This neutrality can be a non-reflexive confusion of the male and the common perspective, but also there are probably ideas of equality at work here-the shaping of an undivided us. Since questions of women's liberation were subordinated to the class contradictions, gender-specific female voices were slow in coming.

Finally, a question can also be raised about the implicit listener. Who was supposed to listen to the music? Was it "The Left," "The People," or a more specific group like workers or the working youth? There is a construed "you" in several songs-mainly someone of the same age, also imagined as the listener. Many songs also turn to an imagined "we," as seen in the discussion above. "We" may include musicians as well as the audience. However, there is a more internal circle of listeners from the music movement present because every song could be observed as a realization of politically progressive music.

\section{Some Notes on a Progressive Poetics}

What genres and modes of expression are used? The various ways to address a theme can be roughly divided into two perspectives. The first perspective is by treating a theme as an abstract concept, possibly clarified with examples and similes, and the second is to use a concrete picture-an "everyday realism" (perhaps autobiographical), that is left without commentary, or accompanied by a more general interpretation at the end of the song (or in a chorus that forms a contrast to the verses).

The most common mode is the voice that speaks in front of an audience: usually implicit, sometimes directly addressed ("Gott folk, kom hit och lyssna"-good people, come here and listen, or "Hör upp allt folk" - listen here all people, which are both examples from Fria Proteatern/NJAgruppen). Sometimes there are complete stories with a well-balanced narrative structure. The ordinary verse/chorus-form of popular music is however not so easily combined with the narrative mode. One notable exception is Gunder Hägg's Glassfabriken where the chorus is changed every time it occurs: "This happened in the forties, when the climate was really hot . . this happened in the fifties, when the climate was rather cool."

A pseudo-narrative mode is more common, in which the main focus is on the conclusion or moral rather than on any narrative tension. Several events can be displayed in different verses; however, there are no causal connections between the events, as they appear just in order to exemplify the point of the chorus in different ways. A pseudo-narrative mode could also consist of descriptions of milieus or persons, listed in a temporal but not necessarily causal order. Hoola Bandoola Band's Birmingham is a personal travelogue, as well as a snapshot of the British class society. Blå Tåget’s Tragedi $i$ kanslihuset (Tragedy in the government building) portrays a social democrat career politician who is proud of his success, but suddenly falls to the floor with a heart attack. Lars Aldman's Atlas Copco is a description of a Swedish-owned multinational company and its ambitions. There is also a more "poetic" portrayal, where something is focused on in a song, but is either left uncommented on or does not serve any rhetoric purpose.

Other songs have more of an introspective quality. They are not aimed outward, but function as

formulations in which to recognize the Self_an "I" or "We." Here there is no pedagogical or agitating 
tone, rather, the voice of a seeker or philosopher. Their direct aim is not to place demands on the listener but to offer the possibility of identifying with the subject of the lyrics.

There are also lyrics that are more formulaic and ritualistic. They do not form a coherent narrative or a descriptive or investigative text, but form simple phrases or words to sing and repeat. For example, the Ho Chi Minh_-slogan or Arbete \& Fritid's song Petrokemi, where "Petrokemi, det kan man inte bada i" (Petrochemistry, you can't bathe in that) are the only lyrics and they are repeated ad infinitum.

As for the speaker's attitude to what is said, the indicative mood is dominant. Lyrics mirror reality or suggest how to interpret reality in a correct way. These "realities" can lead to the imperative mood, reflected in songs of agitation. However, sometimes there is also a subjunctive mood, where either a utopian future or images of "how it could be" are depicted. There are also some examples of the mood of unreality, i.e., lyrics where fantasy takes over. Fantasy is a problem, however, from a leftist view: it could be an example of humanity's inherent creative force, but does not say anything clearly. Therefore it should be anchored in reality by explaining it as a dream, illusion, or a utopia that is worth trying to make real. These explanations guide us back to the imperative mood: "In the seventies social realism was important in rock lyrics, even for us, but we were influenced by surrealism as well, to play with words and rhymes ... We didn't use the correct propaganda template, where all social problems would be analysed, and preferably also be solved with the revolution in the last verse of every tune."14

Some recurrent settings might be called chronotopes of these genres. Contemporary Sweden, Reality, Industry, Institutional Care, the Big City (Stockholm), the Suburb, the working class areas of Gothenburg, the depopulated countryside, the proletarian and fighting Norrland (the northern part of Sweden), and the shabby café of disillusioned intellectuals are different milieus that were used time and time again to make points about contemporary society. In comparison with standard pop songs, where the happy home of the newly weds or the tourist paradise were in focus, these chronotopes indicated places in society where the real things were happening.

Stepping out of the song-worlds of the texts and into the realm of making music (cf. Galloway Young 1987), the contents and the subject positions of the songs were also important in construing the musician roles available. One of the mechanisms behind the relative success of the music movements, I think, is that it supplied new positions and roles for musicians. This made it possible for new musicians to find an audience and also made new musical expressions possible. Among these roles, you could find the sincere musician (jazz, rock, any genre) steering clear of all commercial detours; the alternate music teacher, inviting everybody to take part in collective music; the historian, presenting authentic but forgotten folk music; and the anthropologist, introducing non-European music. However, the dominant focus of my study is viewing song lyrics as a means of shaping positions for musicians. There was an expectation that everybody singing should speak from their own positions and experiences, to be authentic in their lyrics according to the identities they represented. Further, there were some "preferred" identities that functioned for musicians as well as audiences.

One position around 1970 is Youth. Musicians could be or represent young people critical of the parent generation, questioning adult society and protesting against subordination to elders. Here we also find ideas of being true and honest to yourself, to find your inner "I." This is the youth that demonstrate against war and injustices and are confronted with the police force. A youth position can also be provocative (the band Gudibrallan clearly took this stance), ridiculing the church and the students,

\footnotetext{
${ }^{14}$ Thomas Stålberg in CD insert to Kung Tung reissue, 2001.
} 
singing the pros and cons of alcohol, taking more or less a dropout-perspective. From 1972, the "youth"-perspective was played down, probably because extreme emphasis on youth protest would create unwanted divides within the population. Instead, we see signs of respect for elder workers and their experience.

The social critic is an observer or a voice crying in the contemporary wilderness, drawing attention to the many things going astray: the war in Vietnam and other imperialistic wars, the depopulation of the countryside, the pollution of Nature, and social exclusion. Trubadur Cornelis Vreesvijk made his breakthrough with the social-critic image. Rock groups from the early seventies like Contact and Vildkaktus take this perspective. The critical practice of only protesting what is bad, however, eventually lost respect. Around 1973 a common point of critique is "no analysis." Therefore, the social critic position was replaced by those of the teacher and the socialist.

The teacher also draws on social criticism but builds on an analysis of underlying causes and points to possible roads to improvement. The socialists are the teachers, the social critics, everybody included in the fighting "We," and politically conscious people in their everyday reality. In addition to analysis, the agitator has a definite drive to get a leading position for him/herself and his party (this perspective is not strongly present in my sample, since I have not chosen records from specific parties and other organizations). The philosopher also is a social critic, with the job of analyzing complex phenomena and pointing to paradoxes, rather than conveying distinct and simple truths. The feminist, beginning with her own experiences as a woman, is a teacher as well as agitator, who is partly socialist but with women's liberation up front, clarifying how "the private is political."

The worker sings songs from a class perspective. Factory interiors, experiences of unemployment, feelings of inferiority, and social misery are distinct tropes. Having a regional identity sometimes mixes class and geography as articulations of each other. The misfit sings from personal experiences of drug addiction, mental institutions, and prisons. The parameter of the "personal" could count as an authentic expression de-masking the welfare state and, therefore, having a political potential. The "personal" was a rather constricted space, however, since it risked having the singer excluded as a drug romanticist. For the misfit to really qualify, there were expectations of coming to terms with oneself and to change ones lifestyle.

The subject positions expressed in the lyrics were expected to be authentic to the singers, thereby closing the gap between musicians and the imagined audience. Some of the singers and groups named in my survey were highly identified with one of these positions; others could change between them from song to song. However, by following Allan Moore's distinction between first and third person authenticities (2002), there were also opportunities for musicians not identifying with the lyrical subject, but giving voice to an "authentic other." The progressive actors, in the many independent theatre companies that mushroomed in the early seventies, built their professional role on "giving voice to the oppressed," with many plays focusing workers or suburban youth, and written on the basis of interviews. As a result, quite a few songs express these subjects. By going into another people's music, like Chicago blues, a singer could also gain a position and authenticity as a mediator (where the blues as a genuine expression, as well as the singer's ability to mediate it, both would be accounted for as authenticity). I have not discussed these examples in my survey. 


\section{Concluding Remarks}

In the 1960s, records became the primary medium for music. The young people got in touch with music through records, and young would-be musicians thought of making records as a natural part of music-making. Therefore, the rise of the young left also meant that records and song lyrics were taken in as one space to use when experimenting with new subjectivities. In Sweden, this process also lead to a successful break-in by independent companies on the record market, whereby questions of whose voices were represented in popular songs could be raised. Ideas about identity among the young left and who they emotionally and ideologically wanted to connect with are visible in the song lyrics, as well as immediate topics that were considered important in raising social consciousness. However, the Demonstration and the Evening Meeting were still the ideal situations where a politically informed music was supposed to thrive. This attitude is possible to trace in the song formats. The authenticity and sincerity of singers on record could also be questioned; but here, the independent labels served as a guarantee of honesty, as well as the choice of live performances. Not least was the willingness to play for free for the benefit of various causes and a means to establish authenticity. 


\section{Literature}

Bjereld, Ulf and Marie Demker. I Vattumannens tid? En bok om 1968 års uppror och dess betydelse idag. Stockholm: Hjalmarson \& Högberg, 2005.

Eyerman, Ron and Andrew Jamison. Music and Social Movements: Mobilizing Traditions in the Twentieth Century. Cambridge: Cambridge University Press, 1998.

Fornäs, Johan. "'Play it yourself: Swedish music in movement.” Working Paper, JMK, Stockholm University, 1992.

Ganetz, Hillevi. Hennes röster: Rocktexter av Turid Lundqvist, Eva Dahlgren och Kajsa Grytt. Dissertation. Stockholm: Symposion, 1997.

Giddens, Anthony. The transformation of intimacy : sexuality, love and eroticism in modern societies. Cambridge: Polity Press, 1992.

Mosskin, Louise and Peter Mosskin. Ungdomsupproret. Stockholm: Bonniers, 1969.

Palm, Göran. Indoktrineringen i Sverige. Stockholm: PAN/Norstedts, 1968.

Svensson, Birgitta. "Prison Songs as Counter-Memories." In ARV, Nordic Yearbook of Folklore, 113-127. 2001

Young, Katherine Galloway. Taleworlds and Storyrealms:The Phenomenology of Narrative. Dordrecht/Boston/Lancaster: Martinus Nijhoff Publishers, 1987. 